\title{
Konsekwentna realizacja założeń humanistyczno- -antropologicznych w edukacji międzykulturowej nadzieją na bardziej efektywną praktykę społeczną i złagodzenie konfliktów w świecie wielokulturowym (refleksje na marginesie podstaw teoretycznych i efektów działalności Zespołu Pedagogiki Kultury i Edukacji Międzykulturowej przy Komitecie Nauk Pedagogicznych PAN)
}

Streszczenie: Główna teza, podobnie jak charakter artykułu, wynika z jego tytułu i wstępu do niego. Skoncentrowana jest na trzech tematach:

- założenie Zespołu Pedagogiki Kultury i Edukacji Międzykulturowej, jego teoretyczne podstawy, warunki współpracy i ważne osiągnięcia w obu dziedzinach w czasie 12 lat jego istnienia,

- formy współistnienia różnych wspólnot w wielokulturowym świecie, szczególnie skonfliktowanych grup etnicznych i religijnych, w których ekstremalny fanatyzm prowadzi do ludobójstwa, ataków terrorystycznych, powodując masową migrację. Utrzymanie pokoju na świecie jest wyzwaniem dla edukacji wielo- i międzykulturowej, która nie zawsze funkcjonuje dobrze,

- ruch w kierunku realistycznego programu edukacyjnego, łączącego teorię z praktyką. Taki podstawowy i integracyjny program powinien przygotowywać ludzi do życia w dynamicznie zmieniającym się świecie, do budowania ich proaktywnego podejścia do spełniania potrzeb społecznych, duchowych i życiowych, do podnoszenia ich świadomości odpowiedzialności obywatelskiej oraz do uczenia się, jak radzić sobie w trudnych sytuacjach.

Słowa kluczowe: humanistyczno-antropologiczna pedagogika kultury, edukacja wielo- i międzykulturowa

Spośród wielu spotkań naukowych w 2019 roku dwa były mi bliskie głównie z powodu osób, z którymi łączy mnie długoletnia przyjaźń i współpraca, 
i które były szczególnie uhonorowane. Są to w kolejności spotkania: Jerzy Nikitorowicz z okazji 40-lecia pracy - uczczony jako człowiek pogranicza - wyzwania humanistycznej edukacji (21-22 maja, Białystok) i Tadeusz Lewowicki pełniący przez 30 lat w Cieszynie funkcję kierownika zespołu badawczego, co zaowocowało u podopiecznych licznymi doktoratami, habilitacjami, a także profesurami, któremu na Wydziale Etnologii i Nauk o Edukacji został nadany 4 czerwca tytuł Doctora Honoris Causa Uniwersytetu Śląskiego (Edukacja międzykulturowa w Polsce i na świecie: 30 lat doświadczeń problemy - perspektywy).

Sformułowany tytuł moich refleksji jest jednocześnie tezą, która obliguje do lakonicznego uaktualniającego poruszenia (przypomnienia) w bogactwie literatury wyboru - moim zdaniem - istotnych zagadnień, które dotyczą:

- po pierwsze: genezy powołania Zespołu Pedagogiki Kultury i Edukacji Międzykulturowej, założeń teoretycznych współdziałania, osiągnięć i dalszych losów;

- po drugie: istoty nasilających się zagrożeń w wielokulturowym świecie jako palących wyzwań dla edukacji w ogóle, a w szczególności edukacji międzykulturowej;

- po trzecie: sformułowania wniosków odnośnie do obszaru szeroko rozumianej edukacji, a w szczególności międzykulturowej, opartych na racjonalnym powrocie do humanistyczno-antropologicznych ich podstaw jako próby optymalnej odpowiedzi na wyzwania XXI wieku.

\section{Zespół PKiEM: geneza, założenia teoretyczne, formy współdziałania, osiągnięcia i dalsze losy}

Powołanie Zespołu poprzedzone było reaktywowaniem współczesnego nurtu pedagogiki kultury w wyniku organizowanych przeze mnie jako kierownika Zakładu Teorii Upowszechniania Kultury Instytutu Pedagogiki UMCS w Lublinie ogólnopolskich konferencji naukowych. Pierwsza miała miejsce w 1995 roku i datę tę można uznać jako wyznaczającą powrót terminu „pedagogika kultury" jako oficjalnej nazwy dla tego nurtu teorii i praktyki edukacyjnej. Aprobata taka wynikała z wymowy wygłoszonych i opublikowanych referatów. M.in. nestor pedagogów polskich - profesor Stefan Wołoszyn lakonicznie i sugestywnie uzasadnił, że pedagogika kultury nie wymaga restytucji - jest żywa, bo trwałe znaczenie ma dorobek naszych klasyków pedagogiki kultury. Jest żywa w swojej współczesnej konotacji w postaci edukacji kulturalnej, jak także ciągle aktualne i naukowo użyteczne są podstawowe katego- 
rie i rozróżnienia pojęciowe, na których się wspiera. Pełne potwierdzenie tych stwierdzeń stanowiły nie tylko kolejne konferencje i publikowane materiały, ale także w dużej mierze działalność naukowa, organizacyjna (powoływanie zakładów i katedr pedagogiki kultury), edukacyjna (wykłady monograficzne z zakresu aksjologii, pedagogiki kultury) i wydawnicza (w tym wznawianie dzieł klasyków pedagogiki kultury) w wielu ośrodkach akademickich (Gajda, 2006, ss. 129-140). Wzrastająca popularność tego nurtu dawała o sobie znać w edukacji szkolnej.

Swoistą legitymizacją reaktywowania na gruncie polskim współczesnego nurtu pedagogiki kultury było bezprecedensowe wydarzenie w historii nadawania stopni naukowych z pedagogiki. Otóż w 2003 roku na wniosek przewodniczącego Komitetu Nauk Pedagogicznych przy Prezydium PAN prof. Tadeusza Lewowickiego nadano pierwszy raz stopień doktora habilitowanego z pedagogiki kultury. Równie bogatym dorobkiem naukowym, organizacyjnym i publikacyjnym poprzedzającym powołanie Zespołu PKiEM legitymuje się powołany w 1994 roku Zakład Edukacji Międzykulturowej na Wydziale Pedagogiki i Psychologii Filii Uniwersytetu w Białymstoku. Jego inicjator i długoletni kierownik Jerzy Nikitorowicz omówił obszernie osiągnięcia i ewolucję działalności Zakładu w sprawozdaniu o wymownym tytule: Edukacja międzykulturowa. Od federacji zespotów badań pogranicza do Stowarzyszenia Wspierania Edukacji Międzykulturowej (Nikitorowicz, 2011, ss. 115-123). Współpraca między ww. Zakładami układała się wręcz idealnie, stąd też zdecydowano o jej kontynuowaniu.

Powołanie Zespołu PKiEM z inicjatywy Lewowickiego było ukoronowaniem wspomnianych wyżej znaczących osiągnięć. 11 maja 2004 roku w WSP ZNP w Warszawie miało miejsce pierwsze posiedzenie organizacyjne zespołu. Wybrano prezesa (J. Nikitorowicz) i wiceprezesa (J. Gajda) oraz sekretarzy, a także uzgodniono zasady współdziałania oraz perspektywy stymulowania rozwoju obydwu subdyscyplin. Jako główne płaszczyzny współdziałania zespołu przyjęto szerokie ujmowanie kultury i jej humanistyczne rozumienie w pedagogice kultury akcentującej wartości uniwersalne, absolutne, ale także (zgodnie ze współczesnym pojmowaniem idei paidei i humanitas) wartości utylitarne i konsumpcyjne; traktowanie człowieka w kategoriach być i mieć. Podkreślano, że antropologiczne ujmowanie kultury, szczególnie odpowiadające edukacji międzykulturowej, a akcentowanej także w Deklaracji Meksykańskiej z 1982 roku, nie jest obce pedagogice kultury Wzbogaca ono bowiem ogląd rzeczywistości w jej różnorodności kultur, lokalnych i odmienności losów ludzkich, a w tym i wizji świata. Zwrócono uwagę na przyswajanie i two- 
rzenie nowych wartości; na komponent etyczny wynikający z teorii wartości jak godność i odpowiedzialność; na rozwijanie postaw kreatywnych i innowacyjnych. W nazwie Zespołu na pierwszym miejscu znajduje się pedagogika kultury, ponieważ uznano jako znaczące dla edukacji międzykulturowej jej kategorie i podstawy teoretyczne. Nikitorowicz podkreślił to i przypomniał, że kultura, będąc czynnikiem różnicującym, stanowi jednocześnie podstawę do jednoczącego porozumienia, niwelując poczucie wyższości wobec inności i odrębności kulturowej mniejszościowych grup i społeczeństw. Akcentował, że owa inność i odrębność nie może być odrzucana i marginalizowana, bo to prowadzi do wielu cierpień i konfliktów. Zadaniem edukacji międzykulturowej jest troska o zachowanie wielorakich tożsamości przy jednoczesnym zrozumieniu różnic między kulturami dzięki dialogowi i wzajemnym wpływom ma prowadzić do wzbogacenia ich oraz obszarów edukacji w nadziei lepszej egzystencji w społecznościach wielokulturowych, poczynając od pogranicza (Nikitorowicz, 2004, ss. 129-144).

Ustalono, że w ramach zespołu, działającego na zasadzie federacji, na organizowane konferencje będą zapraszane obie strony. Publikacje z zakresu edukacji międzykulturowej będą wydawane przez Wydawnictwo Uniwersyteckie „Trans Humana”, a organem podzespołu pedagogiki kultury będzie wydawany rocznik o tym tytule przez ośrodek lubelski.

Z realizacji ustalonych założeń współpracy i znaczących osiągnięć na pierwszym miejscu należy wymienić wydawany przez Zakład Pedagogiki Kultury Instytutu Pedagogiki UMCS w Lublinie rocznik „Pedagogika Kultury" redagowany przez Dariusza Kubinowskiego Od 2005 roku kolejne 5 tomów to cenna platforma wymiany myśli, zderzenia poglądów i upowszechniania informacji dzięki możliwości zamieszczania tekstów mieszczących się w profilu rocznika - głównie z szerokiego nurtu pedagogiki kultury, ale i edukacji międzykulturowej, a także otwartego dla autorów o różnej orientacji teoretycznej. Do szczególnie cennych i znaczących publikacji Kubinowskiego - nie tylko dla współczesnego nurtu pedagogiki kultury, ale w ogóle dla teorii i praktyki edukacyjnej - należy monografia: Jakościowe badania pedagogiczne. Filozofia - Metodologia - Ewaluacja (2010). Nie sposób nie wspomnieć tu zwartych publikacji pracowników Zakładu Pedagogiki Kultury UMCS w Lublinie, jak: Akademickie ksztatcenie animatorów menedżerów kultury w Polsce pod redakcją Barbary Jedlewskiej (2006), Dom kultury w XXI wieku. Wizje, niepokoje, rozwiazania pod redakcją Barbary Jedlewskiej i Bohdana Skrzypczaka (2009); Wojciecha Bobrowicza: Internet - kultura edukacja (2006) i pod jego redakcją Pedagogika i kultura. Pomiędzy teoria 
a praktyką (2009). Cechą znamienną tych publikacji jest pojmowanie kultury w kategoriach humanistyczno-antropologicznych.Takie rozumienie kultury cechuje także autorów obronionych dysertacji doktorskich, jak: Katarzyny Ziołowicz: Funkcje edukacji regionalnej w gimnazjum, Instytut Badań Edukacyjnych w Warszawie i Agaty Świdzińskiej: Edukacyjne funkcje ośrodków dla cudzoziemców w Polsce, UMCS Lublin.

W analizowanym okresie ukazały się dwa różne pod względem charakteru podręczniki akademickie dotyczące pedagogiki kultury: Janusza Gajdy: Pedagogika kultury w zarysie, (2006 - dwa wydania) i Dzierżymira Jankowskiego: Pedagogika kultury. Studia i koncepcja (2006, 2010). W 2010 roku ukazała się znacząca publikacja zbiorowa o wymownym tytule: Humanistyczno-antropologiczna ewolucja pedagogiki kultury. Konsekwencje dla teorii i praktyki pod moją redakcją. W tym też roku ukazała się nowatorska i w części kontrowersyjna monografia Andrzeja Ciążeli: Polska pedagogika kultury w pierwszej połowie XX wieku.

Poza wymienionymi tu publikacjami jest bardzo wiele różnorodnych i znaczących indywidualnych i zbiorowych prac - istotnych dla teorii i praktyki edukacyjnej - osadzonych w założeniach teoretycznych historycznego i współczesnego nurtu pedagogiki kultury czy nurtu pedagogiki antropologiczno-humanistycznej lub wyraźnie do nich nawiązujących, których nie sposób wymienić. Dlatego też ograniczę się tylko do wielu znakomitych autorów (których wymienię tylko z nazwiska) podejmujących w znanych ich publikacjach problemy aksjologii, obszary edukacji: estetycznej, humanistycznej, medialnej, społecznej, edukację dorosłych. Są to przede wszystkim, Krystyna Ablewicz, Tadeusz Aleksander, Jerzy Damrosz, Maria Gołaszewska, Józef Górniewicz, Jadwiga Izdebska, Stanisław Juszczyk, Janina Kostkiewicz, Stefan Kwiatkowski, Zbigniew Kwieciński, Tadeusz Lewowicki, Bogusław Milerski, Janusz Morbitzer, Jerzy Nikitorowicz, Marian Nowak, Katarzyna Olbrycht, Andrzej Radziewicz-Winnicki, Bronisław Siemieniecki, Wacław Strykowski , Bogusław Śliwerski, Lech Witkowski, Irena Wojnar.

Równie bogate i znaczące są osiągnięcia w subdyscyplinie edukacji międzykulturowej szerzej omówione przez Nikitorowicza w przywołanym już Roczniku Pedagogicznym. Stąd wymienię tu główne osiągnięcia, którymi legitymują się ośrodki akademickie, a w szczególności cieszyński, białostocki, opolski i warszawski WSP ZNP. Pierwszy i czwarty z wymienionych to zasługa Tadeusza Lewowickiego, pod kierunkiem którego były inspirowane i prowadzone liczne badania „uwarunkowań rozwoju dzieci i młodzieży na Pograniczu", których plonem było opublikowanie ponad 20 prac w Wyższej 
Szkole Pedagogicznej w Warszawie, równie cenne monografie zbiorowe z organizowanych przez niego konferencji polsko-ukraińskich dotyczących problematyki edukacji. Lewowicki jako przewodniczący Komitetu Nauk Pedagogicznych starał się inspirować działalność pedagogów wszystkich uczelni, a szczególnie bliskie kontakty miał z Nikitorowiczem z UwB, którego znaczących osiągnięć publikacyjnych i organizacyjnych nie sposób wymienić, a w Uniwersytecie Opolskim z Zenonem Jasińskim, z którego działalności badawczo-publikacyjnej nie można pominąć grantu Poczucie tożsamości narodowej i plany życiowe mieszkańców pograniczy. Z pozostałych ośrodków akademickich trzeba wymienić Uniwersytet Zielonogórski, który we współpracy z Uniwersytetem Warszawskim i Uniwersytetem Humbolta w Berlinie realizował badania Edukacja kulturalna w zwiazkach sq̨iadujących regionów Polski i Niemiec, a których plonem jest cykl publikacji: Europeizacja poprzez edukację kulturalnq w języku polskimi niemieckim pod red. Wiltruda Giesekego i Józefa Kargula.

Osiągnięcia obydwu subdyscyplin, tu tylko wybiórczo zasygnalizowane, były w dużej mierze wynikiem dobrze współpracującego Zespołu PKiEM przez blisko 12 lat. W okresie tym w obu podzespołach dokonała się pozytywna ewolucja ich charakteru w celu unikania błędów i porażek w edukacji. Czy jednak wystarczająca? Ostatnie lata 2016-2019 upływają pod znakiem rozpadu jedności i braku współdziałania, co w pewnym stopniu może osłabiać aktywność pedagogów obu subdyscyplin. Losy zespołu to rozpad, stagnacja i trwanie czy powrót do przemyślanej współpracy to problem, można rzec, nieistotny wobec nasilających się zagrożeń w wielokulturowym świecie jako palący problem w zachowaniu ładu światowego i interesujących nas pedagogów wyzwań dla edukacji w ogóle, a w szczególności edukacji międzykulturowej.

\section{Nasilające się konflikty w świecie wielokulturowym źródłem zagrożeń i niezwłocznym wyzwaniem dla edukacji (zwłaszcza edukacji międzykulturowej)}

Wielokulturowość - jako zjawisko szczególnie nasilające się współcześnie nie należy do nowych w dziejach ludzkości. Potwierdzają to przekazy biblijne, historia starożytnych miast-państw, rozkwit oraz upadek Asyrii, Egiptu, kultury hellenistycznej, cywilizacji Cesarstwa Rzymskiego, a ze wczesnego średniowiecza imperium Karola Wielkiego. Migracje ludności były i nadal są głównym czynnikiem intensywnego rozrastania się miast, stratyfikacji 
społeczności i zróżnicowanej infrastruktury. Analogiczne problemy są też w podobny sposób rozwiązywane. Luksusowe dzielnice elit, odizolowane od dzielnic slumsów, jako swoiste miasta w mieście, budzą skojarzenia ze starożytnym jednomilionowym wielokulturowym Rzymem patrycjuszy i Rzymem plebsu. I tak jak te dwie zróżnicowane grupy społeczności integrowały igrzyska w Koloseum, a Greków olimpiady sportowe, tak mieszkańców faweli i elitarnych dzielnic Rio łączą: entuzjazm dla futbolu jako sportu narodowego, plaża, karnawał i samba jako swoiste ponadczasowe świadectwo ludycznych potrzeb i pokojowego współżycia zróżnicowanych społeczności.

Współistnienie bowiem społeczeństw wielokulturowych od początków dziejów ludzkości układa się między dwoma biegunami: od różnych form pokojowej egzystencji do społeczeństw i państw skłóconych wewnętrznie i silnie zantagonizowanych, gdzie dochodzi nierzadko do zbrojnych konfliktów, okrutnych zbrodni i aktów ludobójstwa. Uwarunkowane jest ono funkcjami, jakie pełni szeroko pojmowana kultura w życiu ludzi: w kształtowaniu ich osobowości, w rozwoju społeczno-gospodarczym, w kreowaniu i utrwalaniu wielopłaszczyznowych tożsamości.

Najogólniej i najkrócej ujmując, pokojowe współistnienie społeczeństw wielokulturowych - łatwe do zaobserwowania na przykładzie megamiast - to: wzajemna tolerancja i w miarę zgodne współżycie różnych grup kulturowych (etnicznych, narodowych, wyznaniowych, doktrynalnych itp.), co pozwala na podtrzymywanie rodzimej (odziedziczonej) tożsamości kulturowej. Przybiera ono różne formy: od izolacji typu historycznej amalgamacji, a współcześnie chińskich dzielnic (chinatown), poprzez akulturację - stopniowe nawiązywanie kontaktów i przejmowanie wzorów z innych kultur oraz różne oblicza asymilacji jako dobrowolnego procesu przyswajania przez mniejszości kultury grupy dominującej; do pełnej integracji w scalającą się kulturę jako podstawę tworzącego się meganarodu. Przykładem takiej wzorowej integracji jest w Europie Szwajcaria - państwo trzech narodowości i tylu oficjalnych języków; kraj, który dzięki demokratycznemu prawodawstwu i ogólnemu dobrobytowi charakteryzuje się wysoką świadomością obywateli w dążeniu do utrzymania jego jedności.

Tu zajmiemy się przeciwstawną grupą społeczeństw wielokulturowych, w których nasilające się antagonizmy stanowią realne zagrożenie nie tylko w dalszym rozwoju tych społeczności, ale także w utrzymaniu ładu i pokoju w świecie jako palącym wyzwaniu dla edukacji.

Źródła konfliktogennym głównych zagrożeń są złożone i zróżnicowane. Wynikają one z uwarunkowań historycznych, a współcześnie przede wszyst- 
kim z charakteru ustrojowego państw oraz ich sytuacji społeczno-politycznej i ekonomicznej - to jest czynników obiektywnych, ale także od czynników subiektywnych - stanowiących sferę duchowości: postaw społeczno-moralnych, poziomu świadomości, identyfikacji obywatelskiej. W oparciu o wydarzenia pierwszej dekady XXI wieku można wskazać źródła najgroźniejszych konfliktów.

Na pierwszym miejscu, po latach, jako najgroźniejszy plasuje się fanatyzm religijny i ideologiczny, co można określić jako swoiste neobarbarzyństwo - odnoszone nie tylko do osób prymitywnych, okrutnych, lekceważących uznane wartości i łamiących w sposób bezwzględny zasady moralne i prawne z niskich pobudek, ale również do ludzi wykształconych i zajmujących bardzo wysokie stanowiska, dzięki czemu mogą podejmować przemyślane zbrodnicze i perfidnie kamuflowane decyzje, które powodują monstrualne straty, przede wszystkim w sferze moralnej. Przykładów jest wiele, stąd ograniczymy się tu do kilku z historii i czasów najnowszych. I tak, w imię przestrzegania w życiu dogmatów religijnych, zbrodnie Świętej Inkwizycji były ówcześnie usprawiedliwiane i legitymizowane przez władze kościelne. Natomiast kolonizacja Ameryki, będąca grabieżą dóbr materialnych, wandalizmem w niszczeniu kultury i aktami ludobójstwa, była nagłaśniana jako misja niesienia wyższej cywilizacji. Analogiczna argumentacja pojawiła się w okresie podbojów kolonialnych, kiedy większość państw europejskich dzieliło swe wpływy narzucając podbitym narodom język i kulturę. Z kolei zbrodnie straszliwego masowego ludobójstwa systemów totalitarnych XX wieku: hitleryzm, stalinizm i mniej znane zbrodnie Polpota, dokonywane były w imię obłąkańczej ideologii jako jedynie słusznej.

Nowymi, niewyobrażalnymi, precyzyjnie przemyślanymi i skutecznie realizowanymi aktami neobarbarzyństwa rozpoczął się wiek XXI. Jednym, najbardziej potwornym z nich, był atak terrorystyczny 11.09.2001 roku w Nowym Jorku na World Trade Center, w którym zginęło 2749 niewinnych osób. Rozpoczął on trwającą i nasilającą się aktualnie psychozę strachu w skali międzynarodowej i stanowił olbrzymi cios w humanistyczne normy współżycia wielokulturowych społeczności i narodów. Osłabła postawa tolerancji wobec obcych kulturowo, a pojawiła się podejrzliwość i wzrosły nastroje nacjonalistyczne i akty wrogości oraz agresji wobec muzułmanów, a tych z kolei do Żydów i chrześcijan. Podpalanie kościołów katolickich i prześladowanie chrześcijan odnotowano nawet w tak tolerancyjnych krajach jak np. Indie. Coraz częstsze przypadki zbrodniczej agresji wobec imigrantów mają miejsce w Europie. Nie są one dziełem tylko ludzi prymitywnych i ubogich, 
zagrożonych bezrobociem, ale nierzadko spowodowane są przez osoby zasobne i wykształcone, opętane skrajnym nacjonalizmem, jak Breivik, który z premedytacją zaplanował i spektakularnie przeprowadził mord cudzoziemskiej młodzieży na wyspie Utoya. Szokujące były nagrania wydarzeń, wręcz ludobójstwa rozgrywające się w Państwie Islamskim, a także opinie na ich temat w państwach kultury zachodniej. Wśród państw kontynentu europejskiego największe poparcie dla Państwa Islamskiego odnotowuje się we Francji, bo aż 15\% całego społeczeństwa, a wśród młodzieży (18-24 lata) - 27\%. Natomiast w Wielkiej Brytanii w tej grupie wiekowej popierających jest 4\%, a wśród czterdziestolatków 11\%. Z kolei w Niemczech największe poparcie wynoszące 4\% odnotowuje się w grupie wiekowej 25-34 lata (https://www.pch24.pl/francja--15-procent-spoleczenstwa-popiera-panstwo-islamskie,24932,i.html). Zbrodnicze ataki terrorystyczne, spowodowane przez osoby opętane skrajnym nacjonalizmem. jak Norweg Breivik, mimo zdecydowanego potępienia zapoczątkowały w Europie znaczący wzrost tendencji nacjonalistycznych, traktowanych przez orędowników tej ideologii jako wyraz postaw patriotycznych. Tak było w latach po wielkim kryzysie w 1929-1933 i tak jest obecnie. Wymownym potwierdzeniem jest popularność w wielu krajach partii politycznych o zabarwieniu wręcz profaszystowskim, jak „Angielska Liga Obrony - EDL” czy nowsza „PEGIDA - Patriotyczni Europejczycy przeciw Islamizacji Zachodu”, a z utworzonych struktur międzynarodowych frakcji „Europa Narodów i Wolności” w Parlamencie Europejskim. Powstała ona z inicjatywy Marine Le Pen, liczy 38 deputowanych z ośmiu państw. Na 100-osobowym zjeździe w lutym 2016 roku w Wieliczce miały miejsce kuriozalne, fanatyczne wypowiedzi, jak: Culligana z Wielkiej Brytanii, że nadzieja jest w wyjściu z UE - jako katastroficznym projekcie, który za sprawą uchodźców spowodował utracenie przez państwa niepodległości; z Polski - ks. T. Guza, że UE przypomina III Rzeszę przez zatracanie człowieczeństwa; z Francji - B. Monota, że euro spowodowało upadek pojęcia narodu i patriotyzmu ekonomicznego.

Szeroki obraz bogatych form zachowań i postaw fanatycznych ludzi o różnym statusie społecznym i zawodowym ukazują także media w Polsce, z Internetem na czele; obraz, który trafnie określa tytuł artykułu: Lincz w sieci. Polowanie na wrogów narodu (Leśniewicz, 2016). Dobitnie podkreślają to dwa zdania w eseju w „The Guradian” C. Daviesa: Pal licho Europę, ważne że się zemścimy (2016), w którym analizuje sytuację obecną w Polsce i w konkluzji solidaryzuje się z Polakami protestującymi w obronie demokracji, rozmontowywanej przez Jarosława Kaczyńskiego i jego teorie spiskowe: 
„Wykorzystywanie symbolu narodowego cierpienia (J.G. - dotyczy pomnika katyńskiego w Krakowie podczas wiecu PiS z okazji Święta Niepodległości w 2015 roku) do celów politycznych i przeciwstawiania Polaków Polakom jest sprzeczne z jakąkolwiek koncepcją patriotyzmu...” (Davies, 2016); „W rozumieniu PiS polscy liberałowie nie tylko są dziedzicami zdradzieckiej kliki Mazowieckiego i władców PRL - reprezentują wszystkie pokolenia zdrajców i wrogów Polski, od Sowietów po nazistów i od kajzera po Katarzynę Wielką..." (Davies, 2016).

I na zamknięcie tej cząstki tematycznej zacytujmy noblistę Güntera Grassa, który w autobiografii: Moje stulecie 1900-1999 (1999), wyszydzając wizytę kanclerza Willy'ego Brandta w Polsce, jednoznaczne samookreślił się jako zagorzały nazista (cyt.): „I kiedy ten zdrajca ojczyzny, który w norweskim mundurze walczył przeciwko nam, Niemcom, przyjeżdża tu z wielką świtą, [...] podaje polaczkom na tacy nasze Pomorze, Śląsk, Prusy Wschodnie, a potem jeszcze jakby na bis w cyrku, rzuca się na kolana...” (s. 195).

Aż trudno uwierzyć, że mógł tak napisać noblista, Europejczyk, Niemiec żydowskiego pochodzenia, uważany za sumienie narodu niemieckiego, a nie mały człowieczek o koślawej psychice. Czy można w tej sytuacji dziwić się, że w niektórych państwach, a zwłaszcza w Anglii, po referendum ujawniła się druga twarz zwolenników brexitu - odżyły uśpione demony skrajnego fanatyzmu: nacjonalizmu, rasizmu, ksenofobii. Nagonka na obcokrajowców przybrała formy agresji nie tylko w mediach, ale i w sferze realnej - na ulicach, w szkołach, w sklepach, zakładach pracy. Najostrzej zaatakowano Polaków. M.in. podpalono szopę, w której od 3 lat mieszkali polscy imigranci na podwórzu Abłamowiczów; mają miejsce zwolnienia z pracy, wypisywane są na budynkach i rozsyłane pocztą obelżywe napisy: „Nie będzie więcej polskiego robactwa, Wrócić do domu polskie szumowiny.... Ale są także pokrzepiające wypowiedzi światłych Brytyjczyków, broniących dobrego imienia imigrantów polskich.

Na drugim miejscu najgroźniejszych konfliktów we współczesnym świecie wielokulturowym trzeba zaliczyć wojny zaborcze o źródła energii, jak podbój Iraku przez USA (przy współudziale wielu państw europejskich, łącznie z Polską), dokonany rzekomo z konieczności zapewnienia pokoju, przez zlikwidowanie produkowanej tam broni atomowej, obalenie znienawidzonego dyktatora i zapewnienie demokracji. W rzeczywistości była to wojna o ropę. Wojna, która po jej symbolicznym zakończeniu trwa nadal i zamiast osiągnięcia spodziewanych krociowych zysków dla agresorów przyniosła nie tylko im milionowe straty i zniszczenie światowej sławy arcydzieł sztuki. 
Pogłębiła ona rów wzajemnej nienawiści, a nawet przepaści między kulturą zachodnią a kulturą islamu, pochłonęła i nadal pochłania liczne ofiary i powoduje nieobliczalne straty moralne. Jej nieprzewidywalnym zbrodniczym owocem było ultrafanatyczne Państwo Islamskie.

Bardziej zakamuflowany charakter mają prowokowane interwencje zbrojne w Afryce w celu zapewnienia sobie wpływów politycznych dla czerpania zysków ekonomicznych z eksploatacji bogactw naturalnych. W przypadku półjawnej agresji na Libię głoszono konieczność udzielenia militarnej pomocy „powstaniu zbrojnemu przeciw znienawidzonemu tyranowi” w celu zaprowadzenia ładu, sprawiedliwości i demokracji. Wyrafinowaną, amoralną strategię owego neobarbarzyństwa w polityce oddaje znany aforyzm Henry'ego Kissingera (amerykańskiego polityka i dyplomaty, wykładowcy Harvardu, laureata Pokojowej Nagrody Nobla za wynegocjowanie wycofania amerykańskich wojsk z Wietnamu): „prawdziwa dyplomacja polega na tym, aby tak długo głaskać psa, póki nie znajdzie się na niego kaganiec" (Angora, 2006, nr 37).

Współcześnie też $\mathrm{w}$ wielu obszarach globu i w poszczególnych państwach dochodzi do ostrych konfliktów etnicznych. Źródła ich bywają wielorakie: od uwarunkowań społeczno-politycznych, zagrożeń w sferze bytowej, przez zadawnione urazy i uprzedzenia do nasilających się napięć: nacjonalizmu, ksenofobii, agresji. Szczególnie istotne są uwarunkowania społeczno-polityczne. W państwach totalitarnych, określanych potocznie jako policyjne, panuje terror, cenzura, restrykcyjne prawodawstwo, brutalne rozprawianie się z opozycją, stąd też powszechnym zjawiskiem jest dyskryminacja narodowościowa, etniczna, kulturowa, religijna i łamanie praw obywatelskich. Powoduje to zejście dyskryminowanych do podziemi, co z kolei skutkuje wieloma patogennymi zagrożeniami, zgodnie ze słowami wieszcza: gwałt niech się gwałtem odciska.

Równie boleśnie odczuwane są zagrożenia w sferze bytowej. Przebiegają one z większą intensywnością i mają wymiar globalny, wynikający z olbrzymiego zróżnicowania ekonomicznego ludności, a zatem wykraczający poza tradycyjne konflikty na tle etnicznym, religijnym czy kulturowym, choć ich nie wykluczają. Zdecydowane pogorszenie się warunków materialnych pociąga za sobą poważne komplikacje życiowe. Utrata pracy i wydłużający się okres bezrobocia prowadzą do bezdomności, rozpadu rodziny i do degradacji osobowości - do łamania zasad moralnych, upadku godności i powiększania się obszaru patologii społecznej, a u osób wrażliwych do depresji, rozstroju psychicznego i nierzadko do samobójstwa. Atmosfera niezadowolenia spo- 
łecznego przeradza się w niekontrolowane akcje protestacyjne, zamieszki uliczne, a także walki zbrojne, masowe emigracje.

Szczególnie groźny dla Europy jest terroryzm tzw. samotnych wilków. Są to młodzi Europejczycy, którzy po wyjeździe w celu przeszkolenia wracają i dokonują we własnym państwie czy kontynencie w pojedynkę (określani jako samotne wilki) okrutnych ataków terrorystycznych. Jest to radykalny zwrot w dziedzinie terroryzmu, szczególnie groźny, trudny do wykrycia, który zamachem na Muzeum Żydowskie w Brukseli w 2014 roku rozpoczął wszechobecną falę przerażającej przemocy. Ochotnicy są ze wszystkich środowisk. Znajdziemy wśród nich nastolatków i osoby dojrzałe; młode kobiety, które poślubiły bojowników poznanych na Twitterze i uczą się od nich sztuki zabijania; drobnych przestępców i sfrustrowane gorszymi warunkami egzystencji drugie pokolenie europejskich muzułmanów; wzorowych studentów, którzy w poszukiwaniu sensu życia przeszli na islam, czy też wyznawców tej religii zradykalizowanych przez charytatywne organizacje i meczety finansowane w Europie przez Arabię Saudyjską i Turcję - państwa będące jednocześnie sojusznikami USA. „Ci bojownicy Państwa Islamskiego - zamyka swoje rozważania S. Laurent - wybrali obóz barbarzyństwa... Wyrzekli się wszelkich naszych wartości: tolerancji, szacunku wobec życia, praw człowieka, a zwłaszcza praw kobiet, demokracji... By je zniszczyć są gotowi oddać życie" (2014, s. 166). To oni byli w marcu 2016 roku sprawcami skoordynowanych zamachów bombowych w Brukseli na międzynarodowym lotnisku i na stacji metra w pobliżu unijnych instytucji; masakry dokonanej w Nicei przez kierowcę, który z dużą szybkością wjechał ciężarówką na promenadę i otworzył ogień do tłumu ludzi powracających z dziećmi z pokazów sztucznych ogni 14 lipca - w święto Republiki, taranując i zabijając ponad 80 osób i raniąc ponad 1000; w kilkanaście dni później poderżnięcia gardła 84-letniemu kapłanowi podczas nabożeństwa i zranienie zakonnicy w prowincjonalnym kościele we Francji. W lipcu tego roku w centrum handlowym Olimpia (Monachium) 18-latek - Niemiec irańskiego pochodzenia - strzelając, zabił 9 osób i 21 ranił, głównie młodzież od 14 do 20 lat i dzieci, krzycząc: "Cholerni cudzoziemcy, jestem Niemcem, dostanę was! Allahu Akbar!” Chociaż nie widząc możliwości ucieczki, sprawca popełnił samobójstwo, doszło do wybuchu powszechnej paniki i fałszywych alarmów, co spowodowało kompletny paraliż miasta, które zamieniło się w oblężoną twierdzę. A zatem cel ataku został z nawiązką osiągnięty.

Pozostaje odpowiedź na niełatwe pytanie o przyczyny tego typu fanatycznych postaw i zachowań terrorystów rodzimych, radykalnie odcinających 
się od kultur kraju urodzenia i nabytego obywatelstwa. Wydaje się, że najbliższe prawdy jest szukanie odpowiedzi w różnicach kulturowych: kultury odziedziczonej przez nich (drugie pokolenie uchodźców) i ich aspiracjach życiowych oraz w warunkach bytowych i kulturze krajów osiedlenia (czytaj europejskiej). Generalizując, przyczyny braku ich integracji kryją się po obu stronach, które tu spróbujemy wypunktować.

Główne przyczyny/czynniki terroryzmu po stronie europejskich muzułmanów:

- Fanatyczna religia, wzywająca do „świętej wojny” przeciw niewiernym. Stąd zabijanie z okrzykiem „Allah Akbar” niewinnych ludzi przez samobójców terrorystów, otoczonych nimbem najwyższej chwały jako świętych męczenników.

- Niekontrolowane równouprawnienie społeczności muzułmanów z rdzenną ludnością tubylczą, w tym w zakresie przywilejów socjalnych i swobód obywatelskich - m.in. działalność sądów szariackich, głoszenie w meczetach, mediach i szkołach ekstremistycznych poglądów i form zachowania. Dodajmy do tego znaczący negatywny wpływ Państwa Islamskiego w stymulowaniu terroryzmu oraz ośrodków z Arabii Saudyjskiej i Turcji, finansujących budowę przedszkoli i meczetów, osiedlanie imamów nadzorujących praktyki religijne i wykładnię ideologii islamu nie do przyjęcia w kulturze europejskiej, powodującą uzasadniony wzrost nastrojów islamofobicznych i wzmocnienie antagonizmów.

- Gettoizacja europejskich muzułmanów zasiedlających ubogie dzielnice dużych miast. Przykładem jest Molenbeek w Brukseli, traktowana jako wylęgarnia terrorystów. Jest tu bowiem wysokie bezrobocie, kwitnie przestępczość, a młodzież z biednych rodzin i klasy średniej, nie uzyskując zadowalających wyników w nauce, nie jest konkurencyjna na rynku pracy, stąd czuje się zagubiona i staje się łatwym łupem agitacji dżihadystów.

Czynniki po stronie państw zachodnich będące przyczyną masowej migracji i terroryzmu:

- Jak już wcześniej pisałem, największym błędem USA i państw europejskich były inwazje zbrojne, kamuflowane misją niesienia wolności i demokratycznego ładu przez obalenie dyktatury w państwach Bliskiego Wschodu i północnej Afryki. Państwa te, na skutek sprzecznych interesów, nie potrafią utworzyć jednolitej koalicji, łącznie z Rosją, dla naprawienia błędów i do szybkiego zakończenia przedłużającej się 
przerażającej w skutkach wojny domowej, która nie byłaby postrzegana w kategorii zderzenia przeciwstawnych cywilizacji czy - jak chcieliby terroryści - jako wojna religijna islamu z chrześcijaństwem.

- Krótkowzroczność w polityce migracyjnej państw europejskich to przede wszystkim brak selekcji w przyjmowaniu uchodźców - nieuwarunkowany potrzebami rynku i rygorystycznie przestrzeganym prawodawstwem, obowiązującym w UE lub kraju osiedlenia. Oznacza to podniesienie i zaostrzenie wymagań w przyznawaniu obywatelstwa i tworzenie sprzyjających warunków do integracji, jak to ma miejsce w Szwajcarii i USA, lub wymaganie pełnej lojalności przy zachowaniu własnej kultury, jak w przypadku imigrantów chińskich. Takie działania są konieczne w celu skuteczniejszego zapobiegania groźbie zamachów terrorystycznych i zapewnienia poczucia bezpieczeństwa wszystkim obywatelom, łącznie z przyjętymi uchodźcami, w imię poszanowania uniwersalnych wartości i humanistycznego charakteru kultury europejskiej, a w tym korekty w słabościach (mankamentach) edukacji.

\section{Niepowodzenia edukacji wielokulturowej i międzykulturowej}

Są one, podobnie jak powodzenia, uwarunkowane dwiema grupami czynników. Są to: 1) czynniki zewnętrzne, obiektywne poza nią, do których zalicza się przede wszystkim sytuację społeczno-polityczną i ekonomiczną oraz istniejące trendy kulturowe; 2) czynniki wewnętrzne subiektywne dotyczące podstaw metodologicznych - oryginalności jej założeń, atrakcyjności oraz stopnia realności ich realizacji. Przypomnienie tych uwarunkowań jest konieczne w zachowaniu w miarę obiektywnego całościowego osądu subdyscypliny w celu uniknięcia dalszych niepowodzeń, jak czynią to wnikliwie Tadeusz Lewowicki i Jerzy Nikitorowicz. Według mojego rozeznania główne przyczyny niepowodzeń tych dyscyplin w XXI wieku można uszeregować w następującej kolejności:

1. Taką obiektywną przyczyną niepowodzeń są odnotowane w pierwszej części referatu przemiany społeczno-polityczne, a zwłaszcza skutki spowodowane atakami terrorystycznymi.

2. Następną i najważniejszą są niefortunne założenia teoretyczne ograniczające się niemalże wyłącznie do postmodernistycznej filozofii kultury, która eksponując znaczenie różnicy i pluralizmu oraz relatywizm wartości, hołduje w edukacji zasadzie, że owe różnice kulturowe (językowe, religijne, obyczajowe), polityczne, społeczne stanowią podstawę kształ- 
towania osobowości, lekceważąc porównanie ich ze społecznością dominującą (większościową), obowiązującym w państwie systemem edukacyjnym. W edukacji międzykulturowej akcentuje się głównie wychowanie w duchu tolerancji i zrozumienia odmiennych cech kultury grup mniejszościowych ze strony grup dominujących, zamiast położyć nacisk na eksponowanie wartości wspólnotowych jako płaszczyzny autentycznego porozumienia i współżycia regionalnego, narodowego, europejskiego i globalnego. Nie zwraca się uwagi, o czym wielokrotnie pisałem, że neurasteniczne, agresywne roszczeniowe zachowanie i lekceważenie zasad współżycia społecznego mniejszościowych grup etnicznych prowadzi do konfliktów, wzrostu wzajemnych uprzedzeń, utrwalenia krzywdzących stereotypów. Zamykanie się we własnej kulturze stygmatyzuje grupę i prowadzi do jej gettoizacji. Poznanie natomiast kultury grupy dominującej, opanowanie języka i norm współżycia zapewnia w sposób naturalny jednakowe traktowanie i drogi awansu społeczno-zawodowego. Oznacza to naturalny dobrowolny proces asymilacji, niesłusznie potępiany, bo nie musi oznaczać utraty tożsamości narodowej, czego wymownym przykładem są rozproszeni po całym świecie Żydzi. Ich wkład w rozwój kultury i ekonomii w poszczególnych państwach ich zamieszkania jest najwyższy.

3. Kolejną bardzo istotną przyczyną niepowodzeń, będącą konsekwencją wcześniej omówionej, jest w ostatnich latach odcięcie się niemalże zupełnie od klasycznego i współczesnego nurtu pedagogiki kultury, który miał stanowić główną płaszczyznę współdziałania Zespołu Pedagogiki Kultury i Edukacji Międzykulturowej. Mam jednak nadzieję, że orientacja humanistyczno-antropologiczna powróci w uaktualnionych formach działania i jako dominująca w edukacji. Służy ona bowiem - powtórzmy - budowaniu głęboko humanistycznych stosunków międzyludzkich, w których nie ma miejsca na wrogość do obcego, na nacjonalizm, fanatyzm polityczny i religijny. Uświadamiając natomiast jednostce jej korzenie i wartości kultury rodzimej, narodowej i światowej, sprzyja jednocześnie otwieraniu na uniwersalne wartości i budowanie wspólnotowego porozumienia oraz szacunku niezależnie od różnic kulturowych, ale o tym szerzej w trzeciej części.

4. Inną istotną przyczyną słabości i niepowodzeń jest brak przełożenia teorii na praktykę. Tego typu zarzut można postawić wielu dyscyplinom, w tym tu analizowanym. Jest on jednak zasadny wtedy, kiedy teorię pozytywnie weryfikuje praktyka, kiedy teoria, trafnie diagnozując zastaną 
rzeczywistość i pojawiające się w niej nowe trendy służy usprawnieniu jej i z myślą o przyszłości kreuje lepszą humanistyczną wizję życia. Jeśli natomiast teoria jest jednostronna, obarczona błędnymi przesłankami lub wręcz szkodliwa społecznie i moralnie, to lepiej, jeśli nie przekłada się na realizację w praktyce. Oceny, jak jest w przypadku analizowanych zagadnień, będą z pewnością bardzo różne i skażone subiektywizmem. Wskazane wyżej główne przyczyny niepowodzeń to trudne wyzwania stojące przed edukacją w ogóle, a w tym proponowaną tu edukacją humanistyczno-antropologiczną.

\section{O realistyczny program edukacji humanistyczno- -antropologicznej jako alternatywy wobec niepowodzeń edukacji wielokulturowej i międzykulturowej}

Oznacza to opowiedzenie się za kształceniem aksjologicznym i uwzględnieniem rzeczywistości realnej - liczeniem się z uwarunkowaniami epoki i potrzebami osób żyjących w zróżnicowanych społecznościach; za optymalnym przygotowaniem do pełnienia różnorodnych ról społeczno-zawodowych, do orientowania się w skomplikowanych problemach współczesnego świata i znalezienia właściwego miejsca dla siebie we wspólnocie ludzkiej. Tego typu realistyczne podejście w edukacji odwołujące się do humanistyczno-antropologicznego rozumienia kultury - harmonijnego łączenia wartości duchowych z wartościami utylitarnymi i konsumpcyjnymi przynosiło w przeszłości sukcesy i jest w dalszym ciągu efektywne w społecznościach wielokulturowych, w których to kultury lokalne, regionalne, narodowe i ponadnarodowe służą kreowaniu różnorodnych tożsamości. Dodajmy: idee te znalazły odbicie w 2008 roku, w ogłoszonym przez Parlament Europejski Rokiem Dialogu Międzykulturowego, a także w Raporcie Międzynarodowej Komisji Rozwoju Edukacji: Uczyć się, aby być, pod redakcją Edgara Faure’a (1975), w którym położono nacisk na wielostronny rozwój człowieka, obejmujący wszystkie dziedziny jego życia, oraz Raporcie dla UNESCO: Edukacja. Jest w niej ukryty skarb pod redakcją Jacques'a Delorsa (1998). W tym drugim sformułowano m.in. cztery filary edukacji: uczyć się, aby wiedzieć, uczyć się, aby działać, uczyć się, aby żyć wspólnie, uczyć się, aby być. Nakreślone w raporcie horyzonty, zasady i kierunki edukacji mają służyć, zdaniem Delorsa, przezwyciężeniu różnorodnych napięć, takich jak między innymi: „tym, co globalne, a tym, co lokalne (...), tym co uniwersalne, a tym, co jednostkowe (...), między tradycją a nowoczesnością (...), działaniem prospektywnym 
a działaniem doraźnym (...), rozwojem wiedzy a zdolnością przyswajania jej (...)” oraz „między duchowością i materialnością”. Stwierdza on, że ludzie są spragnieni ideałów i wartości moralnych, co jako zadanie edukacyjne oznacza wyzwalanie (zacytujmy): „...u każdego zgodnie z tradycją i przekonaniami oraz pełnym poszanowaniem pluralizmu tę wzniosłość myśli i ducha aż do uniwersalności i częściowego przekraczania samego siebie” (1998, ss. 12-14).

Te dwa raporty, nie umniejszając wagi innych tego typu opracowań, są szczególnie znaczące w rozwoju strategii edukacyjnej na XXI wiek. Wiele zawartych w nich propozycji znajduje odzwierciedlenie w późniejszych publikacjach Komisji Rady Europejskiej, takich jak choćby z 2000 roku tzw. Strategia Lizbońska czy z października 2007 roku przyjęty przez Parlament Europejski traktat: Europejskie ramy kwalifikacji dla uczenia się przez całe życie (European Qualifications Framework - EQF).

Postulat zawarty w Raporcie Delorsa: „Edukacja powinna przyczyniać się do powstania nowego humanizmu, w którym będzie dominował komponent etyczny, a wiedza o kulturach i wartościach duchowych różnych cywilizacji i szacunek dla nich zajmą należne miejsce jako niezbędna przeciwwaga globalizacji” (1998, s. 47) należy traktować jako aktualny swoisty uniwersalny postulat, zwłaszcza że znalazł on wielorakie rozwinięcia w znaczących i publikacjach z zakresu edukacji humanistycznej, antropologicznej i międzykulturowej.

Najkrócej ujmując, współcześnie realistyczne kształcenie - to w dużej mierze konsekwencje: harmonijnie łączonej teorii i praktyki oraz przesłania płynącego z humanistyczno-antropologicznego traktowania kultury. Oznacza to:

- szerokie rozumienie kultury i ujmowanie człowieka w czterech kategoriach: jako obywatela małej ojczyzny, narodu (państwa), kontynentu i świata; zwalczania szkodliwych stereotypów, fobii narodowych, antysemityzmu;

- określenie w miarę uniwersalnych postaw aksjologicznych w wychowaniu - łączenia wartości absolutnych, jak prawda, dobro i piękno, poszerzonych o wolność i miłość z wartościami społecznymi, jak: demokracja, tolerancja, solidaryzm społeczny z wartościami pragmatycznymi typu przedsiębiorczość, zdolności menedżerskie, umiejętność radzenia sobie w każdej sytuacji;

- harmonię między wychowaniem do wspólnoty a tendencjami współczesnego człowieka do zaznaczenia swojej indywidualności. W wychowaniu słuszne dążenie do autonomii wymaga krytycznego podejścia m.in. do problematyki kształtowania postaw kreatywnych, aby unikać kształto- 
wania egoistycznych, narcystycznych osobowości, płaskiej mody na oryginalność za wszelką cenę, błyszczenia i zaistnienia medialnego przez ekstrawagancję (niektórzy celebryci). Stąd już Abraham Maslow apelował o kreatywność altruistyczną, a zatem aspekt moralny;

- harmonię między rozumem a emocjami, która pozwala na odwołanie się do żywej wartościowej tradycji, przestrzega przed uleganiem szkodliwym mitom;

- wykorzystanie szans, jakie niosą wartościowe treści w multimediach (kanały propagujące naukę, sztukę, wartości moralne i społeczne typu m.in. Discovery); szans permanentnego edukowania, uczenie krytycznego (czytaj selektywnego i aktywnego) odbioru.

Te bardzo istotne zagadnienia można ująć lapidarnie w cztery bloki tematyczne w proponowanym tu realistycznym, uniwersalnym programie edukacji.

Pierwszym z nich jest orientowanie w problemach współczesnego świata. Bez takiej orientującej wizji nie można egzystować w pełni świadomie. Chodzi tu głównie o kluczowe zagadnienia ujmowane syntetycznie, a dotyczące życia ludzi na naszej planecie: jej zasobów naturalnych, zmian klimatycznych, problemów demograficznych, migracji, wyżywienia i ekologii i zdrowia, zrozumienia dla innych kultur i wychowania dla pokoju.

Drugi blok tematyczny dotyczy podstawowej wiedzy o człowieku i jego świecie wewnętrznym. Wydaje się konieczne całościowe ujęcie istoty ludzkiej w aspekcie biologii, zwłaszcza najnowszych badań dotyczących ciała i cielesności, w aspekcie życia psychicznego i w aspekcie duchowości jako sfer ściśle ze sobą powiązanych; człowieka jako indywiduum, ale i jako członka społeczeństwa; człowieka jako wytwór i twórcę kultury. Szczególnie istotny jest świat wewnętrzny człowieka, sens życia i miłości jako koniecznych do samookreślenia światopoglądu, wyboru stylu i jakości egzystencji. Nie można też zapominać o takiej wartości jak godność, która jest podstawą siły moralnej jednostki. W sumie syndrom wartości uniwersalnych składających się na idealną stronę człowieka, określaną mianem człowieczeństwa.

$\mathrm{Z}$ pojęciem człowieczeństwa łączy się trzeci istotny blok zagadnień dotyczący wychowania obywatelskiego. „Człowiek - pisał Bogdan Suchodolski okazuje się istotą włączoną w środowisko społeczne, przynależną do określonego plemienia czy narodu, do konkretnego państwa. Być obywatelem jest jego moralnym obowiązkiem" (1990, s. 16). Współcześnie związek państwo-naród, narodowość-obywatel nie należą do łatwych ze względu na wielorakie konflikty w wielokulturowym świecie oraz interesujące nas zagadnienia edukacji w kręgu naszej kultury zachodniej i państwach o ustrojach demokratycznych 
w przeciwieństwie do państw totalitarnych, w których trudno mówić o swobodach obywatelskich. Ponieważ zakres władzy i zakres państwa w liberalnych demokracjach kurczy się, stąd też coraz więcej decyzji przypada obywatelom. W państwach zamożnych pojawiają się w obronie własnych interesów nastawienia agresywne wobec migrantów, a ci z kolei nierzadko naruszają przyjęte tu normy obyczajowe i charakteryzują się postawami roszczeniowymi, co rodzi postawy wrogie i konflikty.

Sytuacja taka wręcz uczula na konieczność podejmowania edukacji bycia obywatelem swojej małej ojczyzny (miejscowości, regionu - działań samorządowych), ojczyzny-państwa, ojczyzny-Europy i bycia obywatelem planety Ziemi. Edukacja ta ma swoje podwaliny w Helsińskiej Deklaracji Praw i Obowiązków Obywatela. Podkreślmy - praw, ale i obowiązków - powinności, o których wielu obywateli, w tym zwłaszcza migrantów, zapomina.

Czwarty blok tematyczny to treści pragmatyczne oparte na wartościach utylitarnych, ujmowanie człowieka w kategorii być i mieć. Uwzględnienie wartości utylitarnych i konsumpcyjnych - tych na „mieć”, nie musi przyczyniać się do degradacji osoby ludzkiej, a wręcz przeciwnie - może służyć budowaniu godziwego życia i wysokiej jakości człowieczeństwa, jeśli będzie harmonijnie łączone z wartościami absolutnymi. Potrzebę taką dyktuje codzienna egzystencja - stosunki społeczne, wzrost wartości pracy powodowany powiększającymi się obszarami ubóstwa i widma bezrobocia. Brak pracy oznacza w wielu przypadkach degradację nie tylko społeczną, ale i osobowości, jest źródłem frustracji, sprzyja rozwojowi patologii społecznej. Chodzi zatem w edukacji o wyrabianie umiejętności podejmowania decyzji, o przekonujące zaprezentowanie swoich atutów, o operatywność. Słowem o to, aby wyedukowany osobnik reprezentował postawę humanisty i był jednocześnie konkurencyjny na „rynku osobowości”. Efektem edukacyjnym tak ujmowanej postawy aksjologicznej będzie pracownik kompetentny w swojej dziedzinie, ale jednocześnie sprawny organizacyjnie, umiejący przetwarzać informacje, odporny na niepowodzenia, przedsiębiorczy i skuteczny w działaniu, rozeznany w mechanizmach gospodarki rynkowej, a przez to poszukiwany na rynku pracy. Najkrócej ujmując, chodzi tu o konieczność uwzględnienia w procesie edukacyjnym - poza wiedzą ściśle „fachową” związaną z profilem kształcenia - również praktycznego sposobu myślenia i działania, a zatem pragmatyzmu uwarunkowanego różnorakimi przemianami i tendencjami rozwojowymi. Sprostanie bowiem wymogom rynku oznacza przede wszystkim: edukację do sukcesu i konkurencyjności oraz umiejętności menedżerskie i innowacyjne. 


\section{Bibliografia}

Delos, J. 1998. Edukacja. Jest w niej ukryty skarb. Raport dla UNESCO. Warszawa: Stowarzyszenie Oświatowców Polskich.

Faure, E. 1975. Uczyć się, aby być. Warszawa: PWN.

Gajda, J. 2006. Pedagogika kultury w zarysie. Kraków: Oficyna Wydawnicza „Impuls”.

Gajda, J. 2009. Humanistyczno-antropologiczna ewolucja pedagogiki kultury. Konsekwencje dla teorii i praktyki. Kraków: Oficyna Wydawnicza „Impuls”.

Gajda, J. 2011. Humanistyczno-antropologiczne wartości podstawą uniwersalnego kanonu oświaty. W: Lewowicki, T. red. Całościowe ujęcie edukacji - ku spotkaniu z oświatologia. Warszawa: Wyższa Szkoła Pedagogiczna ZNP, ss. 103-119.

Gajda, J. 2012. Antropologia kulturowa. Wprowadzenie do wiedzy o kulturze. Kraków: Oficyna Wydawnicza „Impuls”.

Gajda, J. 2013. Racjonalny patriotyzm jako antidotum skrajnego nacjonalizmu. W: Nikitorowicz, J. red. Patriotyzm i nacjonalizm. Ku jakiej tożsamości kulturowej? Kraków: Oficyna Wydawnicza „Impuls”, ss. 50-64.

Gajda, J. 2014. Nasilające się zagrożenia w wielokulturowym świecie trudnym wyzwaniem dla edukacji. W: Lewowicki, T., Ogrodzka-Mazur, E., Ogniewjuk, W. i Sysojewa, S. red. Wielokulturowość i edukacja. Warszawa - Cieszyn - Kijów: Wyższa Szkoła Pedagogiczna ZNP w Warszawie, Wydział Etnologii i Nauk o Edukacji Uniwersytetu Śląskiego, Uniwersytet im. Borysa Grinczenki, ss. 99-111.

Gajda, J. i Izdebska, J. red. 2004. Kultura - Wartości - Kształcenie wobec wyzwań i zagrożeń XXI wieku. Suwałki: Wyższa Szkoła Suwalsko-Mazurska.

Kubinowski, D. red. 2004. Kultura - Wartości - Kształcenie. Toruń: Wydawnictwo Adam Marszałek.

Lewowicki, T. 2004. Kultura, wartości i edukacja - o humanistycznej synergii i racjonalnym optymizmie. W: Kubinowski, D. red. Kultura - Wartości Kształcenie. Toruń: Wydawnictwo Adam Marszałek, ss. 42-47.

Lewowicki, T. 2010. Wielokulturowość i edukacja. Ruch Pedagogiczny. 3-4, ss. 5-20.

Nikitorowicz, J. 2004. Edukacja międzykulturowa Założenia i realizacja. Rocznik Pedagogiczny. 27, ss. 129-144.

Nikitorowicz, J. 2011. Edukacja międzykulturowa. Od federacji zespołów badań pogranicza do Stowarzyszenia Wspierania Edukacji Międzykulturowej. Rocznik Pedagogiczny. 34, ss. 115-123. 
Nikitorowicz, J. red. 2013. Patriotyzm i nacjonalizm. Ku jakiej tożsamości kulturowej? Kraków: Oficyna Wydawnicza „Impuls”.

Wojnar, I. 2004. Humanistyczne i antropologiczne rozumienie kultury - kontrowersje i wzbogacenie. W: Kubinowski, D. red. Kultura - Wartości Kształcenie. Toruń: Wydawnictwo Adam Marszałek, ss. 33-41.

\section{Consistent implementation of humanistic and anthropological assumptions in intercultural education as a hope for more effective social practice and for the alleviation of conflicts in the multicultural world (some reflections upon the theoretical foundations and activity results of the Team for Pedagogy of Culture and Intercultural Education at the Committee of Pedagogical Sciences of the Polish Academy of Sciences)}

Abstract: The main thesis and character of this article comes out of its title and introduction. It focuses on three topics:

- establishment of the Team for Cultural Pedagogy and Intercultural Education Team, it's theoretical grounds, terms of cooperation and significant accomplishments in both fields during 12 years of existence;

- forms of coexistence of different communities in the multicultural world, especially of conflicted ethnic and religious groups, where extreme fanaticism leads to genocide, terrorist attacks and internal conflicts causing mass migration. Retaining peace in the world is a challenge for intercultural and multicultural education which does not always work well;

- movement for realistic educational program, which combines theory with practice. Such elementary and integrated program should prepare people to live in the dynamically changing world, build their proactive attitude in satisfying social, spiritual and material needs, raise awareness of being a responsible citizen and teach how to deal with difficult situations.

Keywords: humanistic-anthropological cultural pedagogy, multi - and intercultural education 